\title{
$\mathrm{X}$ 線画像に基づく腰部負荷ウェアラブルセンサの提案と 腰仙椎アライメント推定
}

\author{
土谷 圭央*1，日下 聖*1，田中 孝之 ${ }^{* 2}$ ，松尾 祥和*3 \\ 小田 まこと*4，笹木 工*4，神島 保*5，山中 正紀 ${ }^{* 5}$

\section{A proposal of lumbosacral load wearable sensor and lumbosacral alignment estimation based on X-ray image} \\ Yoshio TSUCHIYA*1 ${ }^{* 1}$ Takasi KUSAKA* ${ }^{* 1}$, Takayuki TANAKA ${ }^{* 2}$, Yoshikazu MATSUO ${ }^{* 3}$, \\ Makoto ODA $^{* 4}$, Tsukasa SASAKI ${ }^{* 4}$, Tamotsu KAMISIMA ${ }^{* 5}$ and Masanori YAMANAKA ${ }^{* 5}$ \\ ${ }^{*_{1},{ }^{* 2}}$ Hokkaidou University, Information Science and Technology, North-14, West-9, Kita-ku, Sapporo-shi, Hokkaido 060-0814, Japan \\ ${ }^{*}$ National Instiure of Technology, Hakodate College, 14-1 Tokura-cho, Hakodate-shi, Hokkaido 042-0953, Japan \\ ${ }^{*}$ Hokkaido University Hospital, North-14, West-5, Kita-ku, Sapporo-shi, Hokkaido 060-8648, Japan \\ ${ }^{* 5}$ Hokkaido University, Faculty of Health Sciences, North-12, West-5, Kita-ku, Sapporo-shi, Hokkaido 060-0812, Japan
}

Received 2 March 2016

\begin{abstract}
Anteflexion of the spine is essential for many physical activities of daily living. However, this motion places the lumbar disks because it generats heavy load due to changes in the shape of the lumbar spine and can lead to low back pain. In older to reduce low back pain, here we proposed a wearable sensor system configuration that can estimate lumbosacral alignment and lumbar load by measuring the shape of the lumbar skin when the lumbosacral alignment changes. The shape of the lumbar skin and posture angle are measured by using curvature sensors and accelerometers. In addition, the system must be constructed in consideration of the physique, in order to absorb in a variety of human. We proposed this system by measuring the body parameters of anteflexion and studied the change in dimensions of the lumbar spine from changes in posture. By extracting the dimensions of the lumbosacral spine in X-ray images, the attitude angle, body surface area and the dimensions of the lumbosacral spine have relevance. The lumbosacral dimensions calibration method was developed by using that relation. Lumbosacral alignment estimation considering the difference in physiques is developed, and lumbosacral spine alignment was to improve the estimation accuracy. The proposed method could improve accuracy lumbosacral alignment estimation.
\end{abstract}

Key words : Wearable sensor, Lumbar spine, Lumbar load constitutional difference, Skin deformation, Individual difference correction

1. 緒言

現在, 腰痛に起因する問題は業種を問わず多くの作業を行う上で問題となっている. 日本国内において, 腰痛患 者に起因する医療費として約 820 億円 (Itoh et al., 2013) が必要となっている. 腰痛問題は国民生活に大きく関係 していることが，上記の数字より分かる．また，そのような腰痛は，国内以外問わず大きな問題となっている．日

No.16-00072 [DOI:10.1299/transjsme.16-00072], J-STAGE Advance Publication date : 18 October, 2016

*1 正員, 北海道大学大学院情報科学研究科（广060-0814 北海道札幌市北区北 14 条西 9)

$*_{2}$ 正員, フェロー, 北海道大学大学院情報科学研究科

*3 函館工業高等専門学校 ( $\mathrm{T} 042-0953$ 北海道函館市戸倉町 14-1)

${ }^{* 4}$ 北海道大学病院 (

*5 北海道大学大学院保健科学研究科（T060-0812 北海道札幌市北区北 12 条西 5)

E-mail of corresponding author: tsuchiya@ssc.ssi.ist.hokudai.ac.jp 


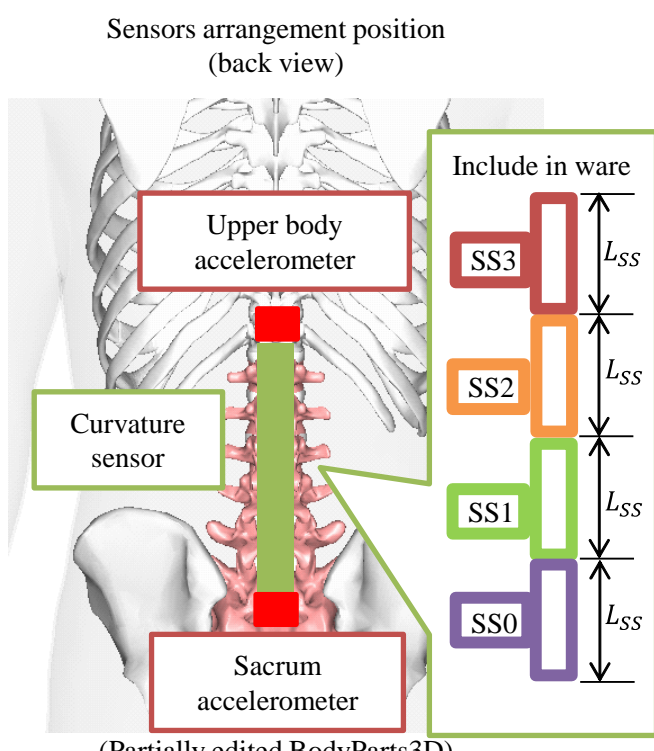

(Partially edited BodyParts3D)

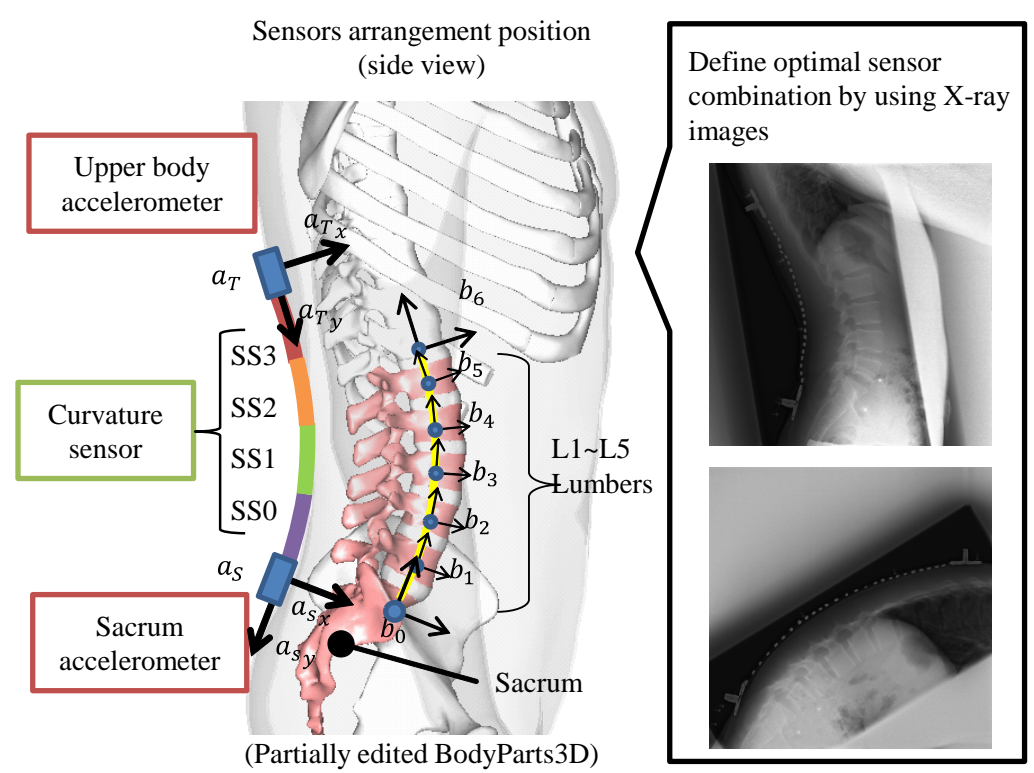

Fig. 1 Sensor arrangement position in wearable sensor system.

本では職場における腰痛予防対策指針 (厚生労働省，2013) があり，アメリカでは介護士の作業に対して，腰部へ の負担を軽減するためのガイドラインが設けられている (Occupational Safety \& Health Administration, 2003). 同 様に NIOSH は, 腰への許容負荷值を $3400 \mathrm{~N}$ と設定しているが, Elfeituri らの研究では, $23 \mathrm{~kg}$ のもりを持ち上 げたときの L5 腰椎と S1 仙骨間への負荷は平均 3685N であった (Elfeituri and Salem，2002). また，NIOSH の基 準に対しての調査は Jagerによっても行われている (Jager and Alwin, 1999).

腰痛の要因として椎間板内圧の増加があげられる。前屈動作を行う際には脊柱において各椎体の間に存在する 椎間板の形状が変化し，それによって脊柱全体の形状が変化することが知られている (但野他, 1991). 各腰椎と仙 骨の位置・姿勢 (アライメントと呼ぶ) などの幾何学的特性である腰仙椎アライメントと椎間板への圧迫力には関 係があり, 姿勢によって腰椎への圧迫力が変化することは, Nachemsonの研究からも知られている (Nachemson, 1976).

これまで我々は，腰仙椎アライメントを考慮した腰部負荷計測を目的とし，表皮形状から体内の情報である腰 仙椎アライメントを推定することで腰部負荷を計測するためのセンサシステムの研究を進めてきた (Hoshina et al., 2012, Tsuchiya et al., 2014). 本研究では本システムをユーザの体格によらず使用できるようにするため，体格や 姿勢による表皮形状, 腰仙部寸法の変化を解剖学的に調べることで, 体格差を考慮した腰仙椎アライメント推定 方法の構築を目指す.

非侵襲的に体内部情報を計測する研究は多く行われている．椎骨が体表面に近いことから 3 次元動作解析装置 を用い，椎体間の変化を捉え椎間板負荷を推定する研究 (芝田他，2012) や，モーションキャプチャを用いて個別 のハンドモデルを構築する研究 (遠藤他, 2013) など, 体内部を推定する方法としてモーションキャプチャなどの 3 次元動作解析装置を利用する方法がある。これらの方法では計測空間の規制があるため常に計測し続けることは 容易ではない．どのような動作であるかを撮影することで負荷を計算する手法としては，腰部負担軽減のための作 業再設計支援ソフトの研究などが行われている (瀬尾他, 1998, 瀬尾, 1999). また, Spinal Mouse(Index Ltd.) を 用いて, 姿勢に応じた春柱のアライメントを計測し, 姿勢における差異において仙骨が大きく変化することを示し ている (河崎他, 2009).これらの研究では, 動作・姿勢を厳密に計測し, 後解析により負荷を算出するものがほ とんどである.この他に, 1 名の介助動作から腰部負荷を計測するため, 接触力を流体圧センサ, 引張力を引張荷 重センサ, 姿勢角度を傾斜計を用いるなど体に取り付けて研究を進めている (山崎他, 2002). この研究のように, 作業者が行う姿勢をリアルタイムで計測し腰部負荷を推定することにより, 作業動作の改善を行うことが出来る. しかし，このシステムは腰仙椎アライメントが変化することが考慮されていない. 
Tsuchiya, Kusaka, Tanaka, Matsuo, Oda, Sasaki, Kamisima and Yamanaka,

Transactions of the JSME (in Japanese), Vol.82, No.843 (2016)

我々が試作したウェアラブルセンサシステムでは, 骨盤と椎体の位置関係を推定することができる (Tsuchiya et al., 2014). 体格によって骨の大きさが変化することが考えられため, 腰仙椎アライメントを推定する上で体格差 を考慮する必要がある．このため，腰仙椎アライメント推定の精度を高めるために体格を考慮する必要がある．試 作したウェアラブセンサシステムを用いて, 腰部負荷の推定まで行っている (土谷他,2014). 腰部負荷を推定する 際に, 腰仙椎アライメント推定情報を用いる. 腰仙椎アライメント推定精度を向上させることによって腰部負荷 推定の精度も向上させることができる.

そこで本研究では, 装着者の体格差を考慮したウェアラブルセンサシステムを設計するために, そのセンサ構 成を検討し，腰仙椎アライメントを非侵襲的に精度良く計測する手法を開発することを目的とする. 各椎体と表 皮の関係は性別, 体型, 姿勢によって変化することが考えられる. そのためセンサが人体のどの位置を計測して いるかを知ることにより，体格差に対してロバストである腰仙椎アライメント推定を実現する．同様に，X線画 像を解析し，腰仙部寸法の体格差補正法を提案する．提案した推定法の精度を X 線画像を用いて評価を行う.

\section{2. 腰仙椎アライメントと表皮形状の関係に基づくウェアラブルセンサシステムの構成}

人体の体幹部を形成している春柱は頸椎, 胸椎, 腰椎の合計 24 個の椎体と仙骨で構成される. 図 1(ライフサイ エンス統合データベースセンター, 2013 一部改編) の中央に示すように, 仙骨の上部に腰椎は 5 つが存在する.こ れまでに外部情報から内部骨格情報を推定する手法として, X 線画像を真值とし股関節中心位置を非侵襲的に推 定する手法 (Kirkwood et al., 1999) や，また， ウェアラブルセンサの一つとしてデータグローブを用いて，手指の 表皮の曲率変化から動作を計測する手法も開発されている (山根他, 2011). 本研究では, これらを腰部に応用し, 腰部表皮形状から腰仙椎のアライメントを計測する．脊柱の棘突起と背面表皮との間は薄い皮膚と体格により多 少の脂肪があるものの, 棘突起の変化は表皮上から捉えることが可能であると考える. また, 本研究においては, 我々の先行研究より, 前屈姿勢の X 線画像から表皮と椎体の関係を見出すことができ (Hoshina et al., 2012), 表 皮線 (Skin line と呼ぶ) と腰仙椎重心を滑らかに通る曲線 (Spine line と呼ぶ) の形状が等価であると仮定し, 腰仙椎 アライメント推定法を行う. 前屈動作姿勢におけるX 線画像の解析から， ウェアラブルセンサシステム設計のた めのセンサ構成を提案する.

\section{$2 \cdot 1$ ウェアラブルセンサシステム}

腰仙椎アライメント推定を行うウェアラブルセンサシステム構成案を図 1 左に示す. センサ配置を決定するた めに, 前屈動作姿勢におけるX X 線画像の解析を行った。解析結果から, 骨盤の姿勢角と Skin line 形状より腰仙椎 アライメント推定を行うことができると考えた。 これを実現する最小数のセンサ構成として，1 つの加速度センサ と複数の曲率センサを提案する. 前屈動作における Spine line と Skin line に関係があり, 腰部表皮上に複数の曲率 センサを取り付け, 形状を取得する. 骨盤姿勢角を計測するために, 仙骨上の表皮に加速度センサ (仙骨加速度セ ンサと呼ぶ) を配置する.さらに, 後述する通り, 体幹の姿勢角が変化することにより腰仙部の寸法が変化するこ とが分かった。体幹姿勢を計測するために，上体 (胸部以上の上半身) に加速度センサ (上体加速度センサと呼ぶ) を配置する．これは，前屈動作時の上体姿勢角を計測するためである.

様々な体格の人を計測するために，曲率センサ配置の最適化を考える，そのため，腰椎長さを考慮するために， 男性 4 名の身体を計測した。人体データベース (AIST，2009) の計測箇所と，L1 から L5 腰椎の突起部の直立姿勢 時の腰椎全長を計測した。人体データベースの後ウエスト高の平均值から求めたところ, 腰椎全長の一般的な長 さは $112 \mathrm{~mm}$ を求めた。このデータベースにおける身長の平均は $1638.1 \mathrm{~mm}$ であるため, 身長の 1 割程度であると 考えられる. 本研究では, 身長 $1800 \mathrm{~mm}$ までの人を計測することを考え, 前屈動作によって背部の皮膚が伸びる ことを考慮して，曲率計測範囲を仙骨から上方に $200 \mathrm{~mm}$ とした．また，曲率センサの数が多いほど，表皮形状の 再現性は高まるが，実用面を考慮するとセンサ数は少なくすべきである，そのため，我々のこれまでの研究成果 (Hoshina et al., 2012) と 54 名の前屈姿勢の X 線画像から実験的にセンサ数の最適化を行った. この結果から, 4 分割で腰部形状を計測できると判断し，各曲率センサの長さ $L_{s s}$ は $50 \mathrm{~mm}$ とした. 
Tsuchiya, Kusaka, Tanaka, Matsuo, Oda, Sasaki, Kamisima and Yamanaka,

Transactions of the JSME (in Japanese), Vol.82, No.843 (2016)

Table 1 Nomenclature.

\begin{tabular}{|c|c|}
\hline Symbol & Name \\
\hline$a_{S}$ & Sacrum accelerometer value \\
\hline $\boldsymbol{a}_{T}$ & Upper body acclermeter value \\
\hline$L_{S s}$ & Curvature sensor length \\
\hline $\boldsymbol{b}_{i}$ & Lumbosacral spine coordinate \\
\hline $\boldsymbol{s}_{i}$ & Skin coordinate \\
\hline $\boldsymbol{s}_{S}$ & Sacrum accelerometer coordinate \\
\hline$\varphi_{b_{i}}$ & Angle of lumbosacral spine coordinate \\
\hline$\varphi_{s_{i}}$ & Angle of skin coordinate \\
\hline$\Delta \varphi_{s_{0}}$ & Correction angle of sacral \\
\hline$d_{i}$ & Distance between skin and vertebrae \\
\hline$l_{i}$ & Interbody distance \\
\hline$l_{s}$ & Distance correction of coordinates \\
\hline$\rho_{s s_{j}}$ & Curvature sensor value \\
\hline$L_{s s_{j}}^{\prime}$ & Curvature sensor length when lumbosacral aliment estimaton \\
\hline$d$ & Average of $d_{i}$ in measurement area \\
\hline$\varepsilon_{i}$ & $\begin{array}{l}\text { The difference between the sum of the sensor } \\
\text { measurement area and the sum of interbody distance }\end{array}$ \\
\hline$\delta_{i}$ & Sign of curvature \\
\hline$\alpha_{l_{\varepsilon_{i}}}$ & $\begin{array}{l}\text { The ratio of the relative range of interbody distance } \\
\text { bottom curvature sensor capable of measuring } \\
\text { the respective vertebral bodies curvature measurement. }\end{array}$ \\
\hline$\theta_{i}$ & Coordinate rotation angle \\
\hline$\rho_{L_{i}}$ & Iertebral body curvature \\
\hline${ }^{i} T_{i+1}$ & Homogeneous coordinate transformation matrix \\
\hline$p_{i}$ & Curvature center coordinate \\
\hline$\varphi_{T}$ & Thoracic spine angle \\
\hline$A$ & Parameter of lumbosacral dimension calibration method \\
\hline
\end{tabular}

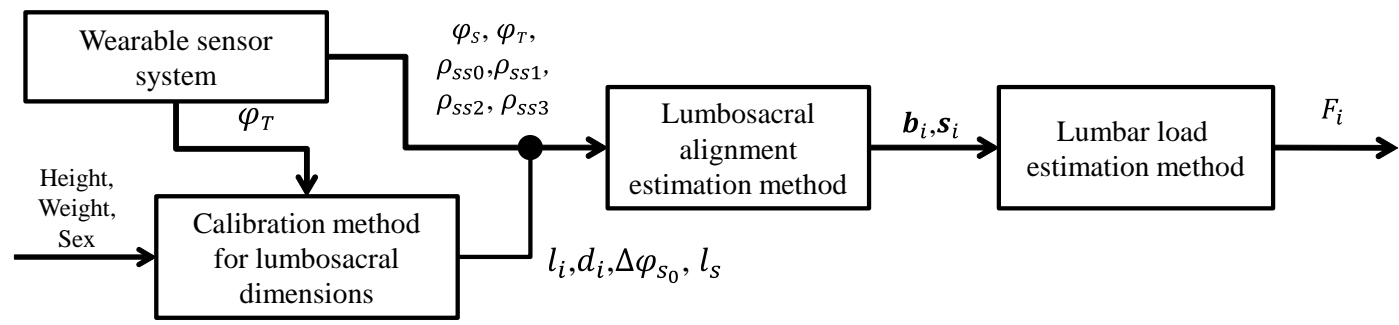

Fig. 2 Estimation algorithm of lumbosacral alignment and lumbar load.

\section{$2 \cdot 2$ 腰仙椎アライメント推定法}

図 2 にウェアラブルセンサシステムを用いた腰仙椎アライメント推定及びその後の腰部負荷推定までの流れを 示す. ウェアラブルセンサシステムとして実装するために，計算コストの低い推定法を構築する必要がある.この ため, 座標変換行列を用いた順運動学的アプローチにより腰仙椎アライメントを求める. Skin line と Spine line が 部分的に同一の曲率中心を持つものとする.このことに着目し, 腰部曲率を用いて腰仙椎アライメントを推定す る. 本推定法は, 図 1 における曲率センサ 4 組から取得する曲率 $\rho_{S S_{j}}(j=0 \sim 3)$ と, 仙骨加速度センサから計測 


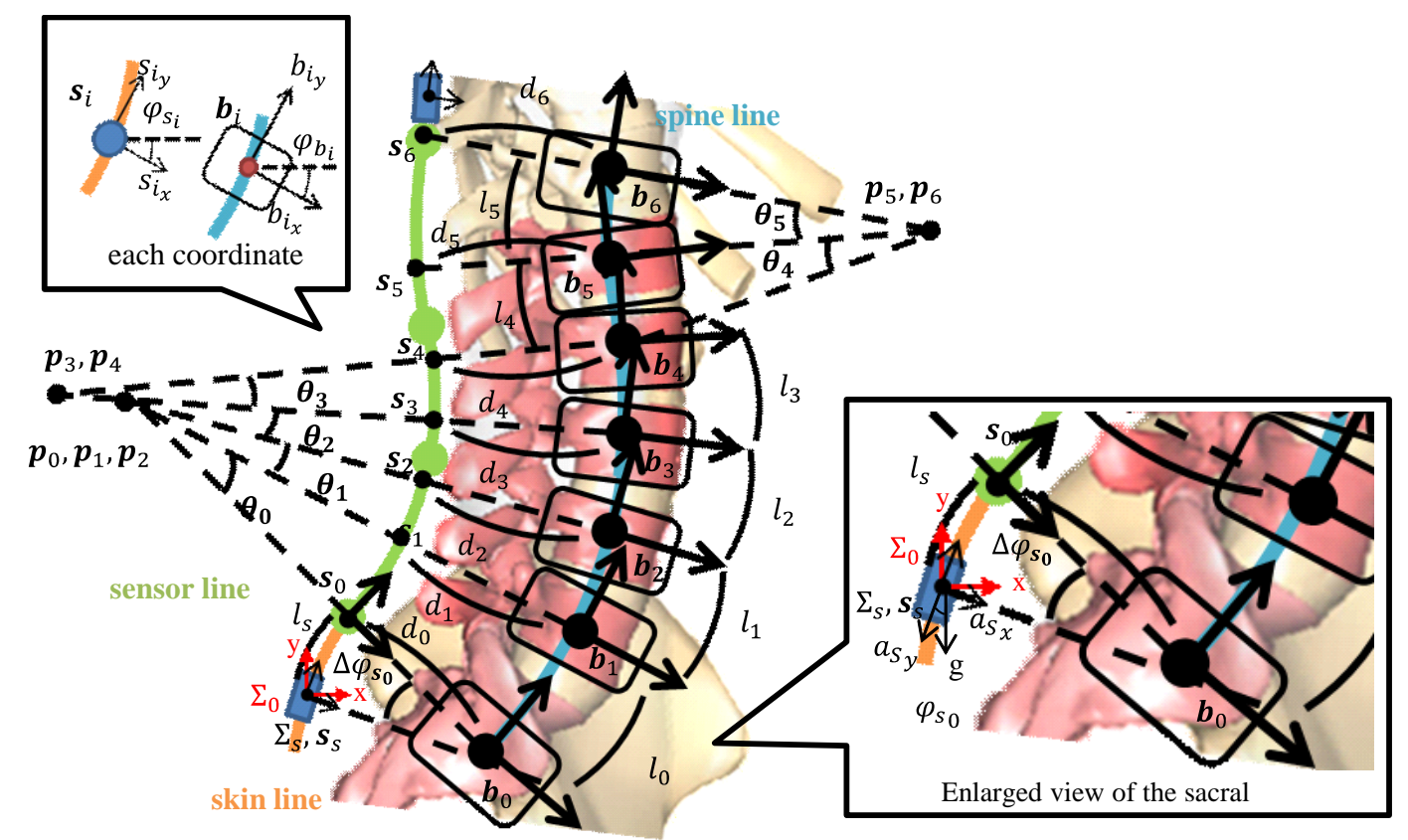

Fig. 3 Lumbosacral coordinates and each parameters. This model is based on the lumbosacral alignment estimation.

Axis and angle of each coordinate are defined by this figure.

した加速度 $\boldsymbol{a}_{S}$ を利用した推定法である.ここでは $j$ は, 曲率センサの番号を示す. 腰仙椎アライメント推定法に よる推定結果のイメージを図 3 に示す. Spine line は推定する椎体重心点 $\boldsymbol{b}_{\mathbf{0}}$ から $\boldsymbol{b}_{\mathbf{6}}$ を滑らかに結ぶ曲線である. 表皮点 $s_{0}$ は, 仙骨加速度センサが取り付けられた位置とする. 表皮点 $s_{1}$ から $s_{6}$ は推定した椎体重心から $\mathrm{x}$ 軸に 延長し表皮と交わる点である. Skin line は，表皮点を滑らかに曲線で結んだものである．各曲線における曲率は連 続的に変化するが，各椎体間では同一とみなす， $\boldsymbol{p}_{i}$ は， $\boldsymbol{b}_{\boldsymbol{i}}, \boldsymbol{b}_{i+1}$ 間において一様曲率とした場合の曲率中心の座 標となる. 最下部から数えた椎体番号を $i$ とし，推定する表皮位置ベクトル $\boldsymbol{s}_{i}$ と椎体位置ベクトル $\boldsymbol{b}_{i}$ とする. 表 1 に，本稿で使用する変数を示す.

まず，図 3 のように仙骨加速度センサの位置座標系 $\boldsymbol{s}_{S}$ に骨盤座標系 $\sum_{s}$ を設ける. 基準座標系 $\sum_{0}$ については, $\sum_{s}$ と同一の原点とし，基準座標系の $\mathrm{y}$ 軸を重力方向とする．鉛直上向きを $\mathrm{y}$ 軸，水平方向を $\mathrm{x}$ 軸とする．仙骨 $\mathrm{S} 1$ の表皮位置べクトル $s_{0}$ とする．しかし，体格によって $s_{S}$ と $s_{0}$ に距離 $l_{s}$ が生じる．そのため， $l_{s}$ を考慮した $s_{0}$ を

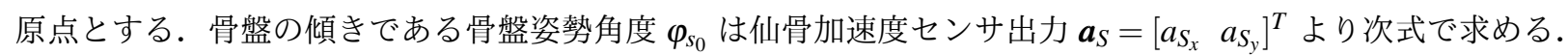

$$
\varphi_{s_{0}}=\tan ^{-1}\left(\frac{a_{S x}}{a_{S y}}\right)
$$

ここでは，表皮-椎体重心間距離 $d_{0}$ として， $\varphi_{a_{S}}$ から $\Sigma_{s}$ 座標系での $\boldsymbol{b}_{0}$ を式 (2) から求める.

$$
\boldsymbol{b}_{\mathbf{0}}=\left(\begin{array}{c}
d_{0} \cos \left(\varphi_{s_{0}}+\Delta \varphi_{s_{0}}\right) \\
d_{0} \sin \left(\varphi_{s_{0}}+\Delta \varphi_{s_{0}}\right)
\end{array}\right)
$$

先行研究によって，一般的に男女では骨盤の傾きは異なることが知られている (松村他，2013). また，仙骨加速 度センサからの骨盤角度と実際の骨盤角度が異なる．このため骨盤の傾き角を補正するために $\Delta \varphi_{s_{0}}$ を考慮して $b_{0}$ を求める. 次に, 図 4 に示すように曲率センサ值 $\rho_{s s_{j}}$ から椎体曲率 $\rho_{L_{i}}$ を求める. 曲率中心が Spine line, Skin line に対して体の前後どちらに存在するかは, 推定時に利用する椎体曲率の符号で判断し, 後屈方向を負, 前屈方向 を正とする.ここで, 曲率センサの長さ $L_{S S}=50 \mathrm{~mm}$ は一定であるが, Spine line の形状は姿勢によって変化するた め, 1 つの曲率センサ $S S_{j}(j=0 \sim 3)$ で計測できる Spine line の長さ $L_{s s_{j}}^{\prime}$ は以下の式で求める.

$$
L_{s s_{j}}^{\prime}=\left(1 / \rho_{s s_{j}}+d^{\prime}\right) \sin \left(\frac{L_{s s}}{1 / \rho_{s s_{j}}}\right) \approx \frac{\left(1 / \rho_{s s_{j}}+d^{\prime}\right) L_{s s}}{1 / \rho_{s s_{j}}}
$$


上式おける $d$ は，その曲率センサが覆う椎体の表皮-椎体重心間距離 $d_{i}$ の平均值を用いる． $\mathrm{i}$ 番目までの椎体位置 を推定する場合, $\boldsymbol{b}_{0}$ から $\mathrm{i}$ 番目までの椎体重心間距離の総和と, 計測範囲を覆う $\mathrm{j}$ 番目までの曲率センサ長の総和 の差分 $\varepsilon_{i}$ ただし $\left(\varepsilon_{i}>0\right)$ として, 以下の式より求める.

$$
\varepsilon_{i}=\sum_{k=0}^{i} l_{k}-\sum_{k=0}^{j} L_{s s_{k}}^{\prime}
$$

使用する表皮曲率を計測した曲率センサの番号を $j$ と示し， $\varepsilon_{i}$ を最小となる $j$ を選択する．次に曲率センサから 各椎体曲率に変換するために次式を用いる.

$$
\rho_{L_{i}}=\delta_{i} \frac{\left|\rho_{s s_{j}}\right|\left|\rho_{s s_{j+1}}\right|}{\left(1-\alpha_{l_{\varepsilon_{i}}}\right)\left|\rho_{s s_{j+1}}\right|+\alpha_{l_{\varepsilon_{i}}}\left|\rho_{s s_{j}}\right|}
$$

各椎体曲率を求めるために使用する $\alpha_{l_{\varepsilon}}$ は, 計測範囲を覆っている曲率センサの最も上部にある計測範囲の長さ と, 椎体重心間距離に対しての割合を示す. $\delta_{i}$ は各椎体曲率の正負の判定をし, 以下の式より求める.これらの 結果を踏まえて $\alpha_{l_{\varepsilon_{i}}}$ を計算する.

$$
\begin{aligned}
& \alpha_{l_{\varepsilon_{i}}}=\left\{\begin{array}{cc}
\frac{l_{i}-\varepsilon_{i}}{l_{i}} & \left(\varepsilon_{i}>0\right) \\
1 & (\text { otherwise })
\end{array}\right. \\
& \delta_{i}= \begin{cases}\operatorname{sign}\left(\rho_{s s_{j}}\right) & \left(\alpha_{l_{\varepsilon_{i}}} \leqq \frac{1}{2}\right) \\
\operatorname{sign}\left(\rho_{s s_{j}+1}\right) & \left(\alpha_{l_{\varepsilon_{i}}}>\frac{1}{2}\right)\end{cases}
\end{aligned}
$$

本研究では, 曲率センサの計測範囲が広い方のセンサ值の正負をもとに椎体曲率の正負を判定し利用する．式 (8) を利用して図中の各角度 $\theta_{i}$ を求める. この時の反時計回りを正として角度をとる. 各角度 $\theta_{i}$ を利用して, 各座標 系を仙骨の座標から順に下から求める.

$$
\theta_{i}=\frac{l_{i}}{d_{i}-1 / \rho_{L_{i}}}
$$

Skin line, Spine line 上の各座標を繋ぐ曲率中心点 $\boldsymbol{p}_{i}$ を式 (9) から求める.

$$
\boldsymbol{p}_{i}=\left(\begin{array}{c}
s_{i x}+\frac{1}{\rho_{L_{i}}} \cos \varphi_{b_{i}} \\
s_{i y}+\frac{1}{\rho_{L_{i}}} \sin \varphi_{b_{i}}
\end{array}\right)
$$

各椎体位置の姿勢角 $\varphi_{b_{i}}$ および, 各表皮位置の姿勢角 $\varphi_{s_{i}}$ は, $\varphi_{b_{i}}$ と $\varphi_{s_{i}}$ は等価であり, 下式より求まる.

$$
\varphi_{s_{i+1}}=\sum_{k=0}^{i} \theta_{i}+\varphi_{s_{0}}+\Delta \varphi_{s_{0}}
$$

曲率中心を原点とする座標系から $\theta_{i}$ 回転させることによって，次の表皮点，椎体位置を次式の同次座標変換行列 ${ }^{i} \boldsymbol{T}_{\boldsymbol{i}+1}$ を用いて求める. この同次座標変換行列 ${ }^{i} \boldsymbol{T}_{\boldsymbol{i}+1}$ は, 3 つの変換を持つ. まず, $\boldsymbol{b}_{i}$ 座標系から曲率中心 $\boldsymbol{p}_{i} \wedge の$ 移動を行う. 次に, 曲率中心心 $\boldsymbol{p}_{i}$ からの回転を行う. 最後に, $\boldsymbol{p}_{i}$ から心 $\boldsymbol{b}_{i}$ までの移動を示す.

$$
{ }^{i} \boldsymbol{T}_{\boldsymbol{i}+1}=\left(\begin{array}{ccc}
1 & 0 & p_{i_{x}} \\
0 & 1 & p_{i_{y}} \\
0 & 0 & 1
\end{array}\right)\left(\begin{array}{ccc}
\cos \theta_{i} & -\sin \theta_{i} & 0 \\
\sin \theta_{i} & \cos \theta_{i} & 0 \\
0 & 0 & 1
\end{array}\right)\left(\begin{array}{ccc}
1 & 0 & -p_{i_{x}} \\
0 & 1 & -p_{i_{y}} \\
0 & 0 & 1
\end{array}\right)
$$

$i+1$ 番目に推定する椎体座標 $\boldsymbol{b}_{i+1}$ に同次座標行列 ${ }^{i} \boldsymbol{T}_{\boldsymbol{i}+\boldsymbol{1}}$ を対応させ, 各座標を (12) で求める.

$$
\left(\begin{array}{c}
\boldsymbol{b}_{i+1} \\
1
\end{array}\right)={ }^{i} \boldsymbol{T}_{i+1}\left(\begin{array}{c}
\boldsymbol{b}_{i} \\
1
\end{array}\right)
$$

表皮座標 $\boldsymbol{s}_{i+1}$ は，椎体座標 $\boldsymbol{b}_{i+1}$ から式 (13) を用いて求める.

$$
\boldsymbol{s}_{i+1}=\left(\begin{array}{c}
b_{i+1_{x}}-d_{i+1} \cos \varphi_{b_{i+1}} \\
b_{i+1_{y}}-d_{i+1} \sin \varphi_{b_{i+1}}
\end{array}\right)
$$

以上より, 腰仙椎アライメントを推定することができる. 


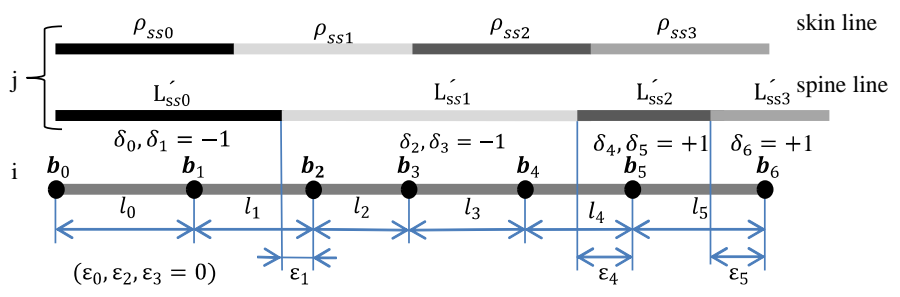

Fig. 4 Relationship between the measurement area of each curvature sensor and each lumbar estimation coordinate.

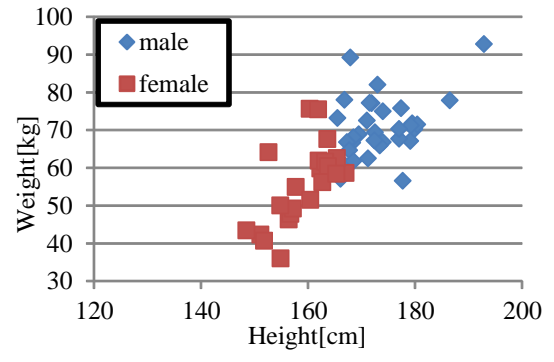

(a) Subjects's distribution of weight and height.

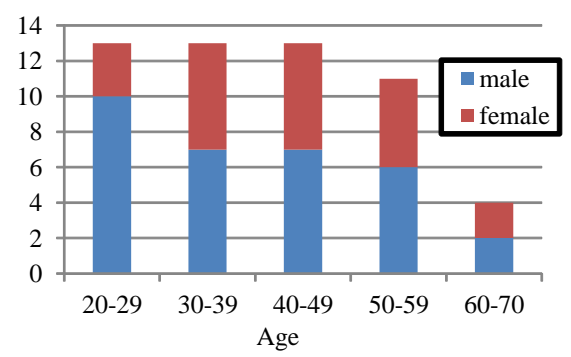

(b) Age of subjects.

Fig. 5 Subjects's distribution

\section{3. 腰部 $\mathbf{X}$ 線画像に基づく体格差補正}

本研究では，ユーザの体格や性別によらず使用できるウェアラブルセンサシステムの開発を目指さしている. 体 格によって骨格の長さや皮膚の厚みが変化することは自明であり, 性別によって骨盤形状に差異があることが知ら れている.これらは, 姿勢変化によって変化することも考えられる.つまり図 3 に示す, 腰仙椎アライメント推 定法に用いる特徵量 $l_{i} \cdot d_{i} \cdot \Delta \varphi_{s_{0}} \cdot l_{s}$ は, 体格・性別・姿勢によって変化し, 腰仙椎アライメント推定の精度に影 響を及ぼすと考えられる。そこで，体格，性別の異なる 54 名の被験者の腰仙部 X線画像を撮影し，体格，性別， 姿勢と各パラメータ $l_{i}, d_{i}, \Delta \varphi_{s_{0}}, l_{s}$ との関係を実験的に求める.これにより装着者の体格や性別によらない, 高 精度な腰仙椎アライメント推定を実現する. 本研究においても, 性別及び, 身体特徴量を用いることで, 体内に おける寸法の体格差を補正する。

\section{$3 \cdot 1$ 腰部 X 線画像における腰仙椎の寸法抽出}

前屈動作における各パラメータの変化を取得するために，腰部 X 線画像を撮影した．様々な体格の人に合わせ 込むために体格差を考慮した腰仙椎アライメント推定法を構築するために, 54 名の X 線画像から各体内寸法の補 正式を求める.X 線撮影は, 医師の指示のもと本研究グループで行い倫理審査員会の承認を得ている(自主臨床試 験番号 1103-0016). 被験者は健常者であり，撮影前にインフォームドコンセントを行い同意書に署名をもらって いる. 直立姿勢 (posture1), 前屈姿勢 (posture2), 最大前屈姿勢 (posture3)の 3 姿勢を撮影した. 被験者の分布図を 図 5 に示す. 体格差を考慮するために, 図 6 のように撮影した 162 枚の X 線写真から腰仙部寸法の真值を抽出し た．撮影した X 線画像から椎体座標系を抽出する方法を以下に示す.

1. X 線画像のコントラストを調整し，各椎体の端点を 4 つ結び長方形として近似する

2. 長方形の対角線の交点を各椎体の重心位置 $\boldsymbol{b}_{i}$ と定義する

3. 各椎体の座標は．鉛直上向きを $\mathrm{Y}$ 軸，水平方向を $\mathrm{X}$ 軸とする

4. X軸を表皮上まで延長し，表皮と交わる点を各表皮点 $\boldsymbol{s}_{i}$ とする

これらの過程を踏まえて, X 線画像から各パラメータを抽出する. 椎体重心間距離 $l_{i}$, 表皮-椎体重心間距離 $d_{i}$ は 以下の式より求める.

$$
l_{i}=\left|\boldsymbol{b}_{i+1}-\boldsymbol{b}_{i}\right|
$$




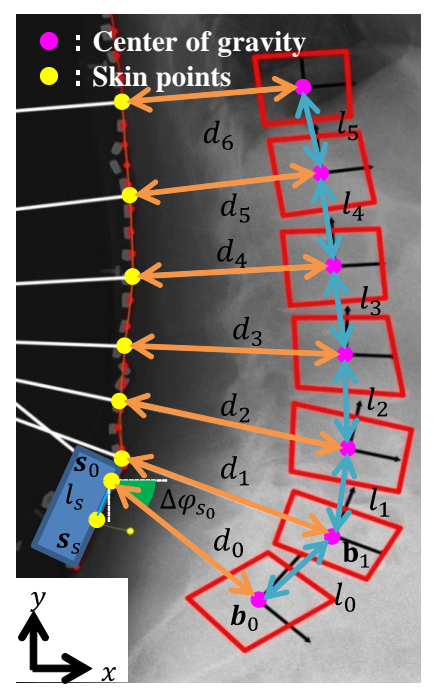

Fig. 6 Lumbosacral parameters extracted from X-ray image.

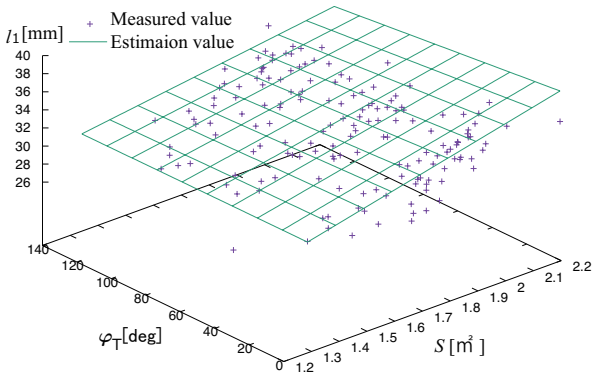

(a) Interbody distance $l_{i}$.

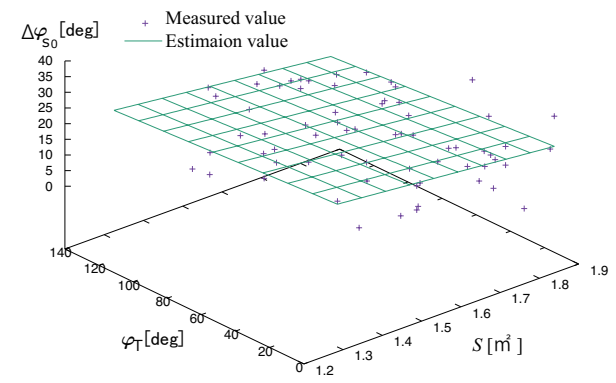

(c) Correction angle $\Delta \varphi_{S_{0}}$ of sacral.

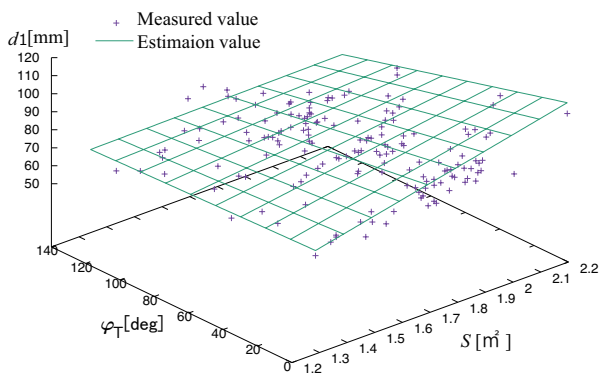

(b) Distance $d_{i}$ between skin and vertebrae.

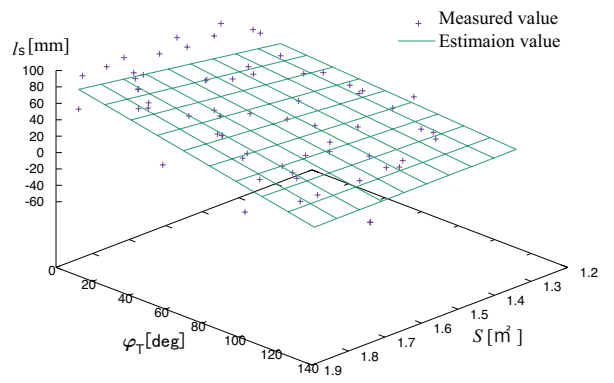

(d) Distance $l_{s}$ correction of coordinates.

Fig. 7 Parameter distribution by changing in the posture angle and body surface area.

$$
d_{i}=\left|\boldsymbol{s}_{i}-\boldsymbol{b}_{i}\right|
$$

仙骨部補正角 $\Delta \varphi_{s_{0}}$ については, 仙骨加速度センサ取り付け位置の表皮点 $\boldsymbol{s}_{S}$ の $\mathrm{y}$ 軸と $\boldsymbol{b}_{0}$ の $\mathrm{y}$ 軸との傾き方算出す る. 腰仙椎アライメント座標原点に体格差 $l_{s}$ については以下の式より求める.

$$
l s=\left|\boldsymbol{s}_{0}-\boldsymbol{s}_{S}\right|
$$

取得した各パラメータについて推定法を構築する.

抽出した腰仙部寸法と身体特徴量の関係式を構築し，個別の腰仙部寸法に補正する方法を提案する．体格差を 体表面積用いて補正する. 本研究では, 藏澄らの推定式を用いて, 身長 $h[\mathrm{~cm}]$, 体重 $w[\mathrm{~kg}]$ から体表面積 $S_{*}\left[\mathrm{~m}^{2}\right]$ よ り求める。男性は式 (17), 女性は式 (18) を用いて推定する(藏澄他，1994).

$$
\begin{aligned}
& S_{M}=0.0053189 w^{0.364} h^{0.833} \\
& S_{F}=0.0110529 w^{0.445} h^{0.627}
\end{aligned}
$$

\section{$3 \cdot 2$ 腰仙部寸法の体格差補正}

撮影した直立姿勢 (posture1), 前屈姿勢 (posture2), 最大前屈姿勢 (posture3) における 54 名分の腰仙部寸法パラ メータ $l_{i}, d_{i}, \Delta \varphi_{s_{0}}, l_{s}$ と体表面積 $S$, 上体姿勢角 $\varphi_{T}$ との関係をそれぞれ図 7 に示す. 図 7 の推定值については 後で論述する. 各姿勢において上体姿勢角 $\varphi_{T}$ の目標值を $0,45,90$ 度と設定した。椎体重心間距離，表皮-椎体 重心間距離は代表データとし第 5 椎体に関する寸法である $l_{1}, d_{1}$ を図に示す.どちらのパラメータも上体姿勢角 $\varphi_{T}$, 体表面積 $S$ に対して変化していることが読み取れる. また， 2 つのパラメータの他部位における結果は同様 の傾向を示した．仙骨部補正角 $\Delta \varphi_{s_{0}}$ の女性被験者の結果を図 7(c) に示す. $S$ と $\varphi_{T}$ に関して，分布していること が図から読み取れる，男性被験者についても同様に，姿勢と体表面積によって変化している， $l_{s}$ に関して，女性被 験者の結果を図 7(d) に示す. $S$ と $\varphi_{T}$ に対しての変化が見られる. 男性被験者についても同様に，上体姿勢角と体 表面積によって変化が見られる. 体格差補正を行うパラメータとして, 上体姿勢角 $\varphi_{T}$ と体表面積 $S$ を用いる.こ れらのパラメータを補正する係数を 2 つ変数から取得する必要がある. 効果的に各パラメータの係数を決定す るために, $S \varphi_{T}$ の項を設けうる。これは，図 7 から各パラメータは上体姿勢角 $\varphi_{T}$ と体表面積 $S$ は交互作用がある ためである. よって，パラメータ補正として $S \varphi_{T}, S$ と $\varphi_{T}$ の 3 つ項を利用する. そこで，上体姿勢角 $\varphi_{T}$ は上 
Tsuchiya, Kusaka, Tanaka, Matsuo, Oda, Sasaki, Kamisima and Yamanaka,

Transactions of the JSME (in Japanese), Vol.82, No.843 (2016)

Table 2 Calibration parameters for interbody distance $l_{i}$.

\begin{tabular}{c|c|c|c|c|c}
$\mathrm{i}$ & $\alpha_{l_{i}}$ & $\beta_{l_{i}}$ & $\gamma_{l_{i}}$ & $c_{l_{i}}$ & $R$ \\
\hline 0 & 0.006 & 4.288 & -0.006 & 27.236 & 0.240 \\
1 & -0.022 & 7.216 & 0.028 & 21.969 & 0.437 \\
2 & -0.011 & 6.969 & 0.007 & 22.931 & 0.476 \\
3 & -0.024 & 6.477 & 0.032 & 23.303 & 0.411 \\
4 & -0.015 & 5.722 & 0.016 & 23.067 & 0.418 \\
5 & -0.004 & 5.677 & 0.002 & 20.805 & 0.453 \\
\hline
\end{tabular}

Table 3 Calibration parameters for distance $d_{i}$ between skin and vertebrae.

\begin{tabular}{c|c|c|c|c|c}
$\mathrm{i}$ & $\alpha_{d_{i}}$ & $\beta_{d_{i}}$ & $\gamma_{d_{i}}$ & $c_{d_{i}}$ & $R$ \\
\hline 0 & -0.357 & 44.247 & 0.467 & 2.024 & 0.617 \\
1 & -0.246 & 34.376 & 0.286 & 28.163 & 0.626 \\
2 & -0.209 & 31.556 & 0.258 & 31.187 & 0.564 \\
3 & -0.196 & 30.649 & 0.258 & 29.212 & 0.523 \\
4 & -0.190 & 29.564 & 0.262 & 26.844 & 0.512 \\
5 & -0.186 & 28.714 & 0.258 & 25.476 & 0.500 \\
6 & -0.169 & 27.760 & 0.226 & 26.092 & 0.518 \\
\hline
\end{tabular}

体加速度センサ出力 $\boldsymbol{a}_{T}=\left[\begin{array}{ll}a_{T_{x}} & a_{T_{y}}\end{array}\right]^{T}$ より次式で求める.

$$
\varphi_{T}=\tan ^{-1}\left(\frac{a_{T x}}{a_{T y}}\right)-\varphi_{a_{T_{0}}}
$$

$\varphi_{a_{0}}$ は直立姿勢時の $\varphi_{a_{T}}$ である. 前述にように，一般的に男女では骨盤の傾きが異なることが知られていること から，仙骨部補正角 $\Delta \varphi_{s_{0}}$ と腰仙椎アライメント座標原点に体格差 $l_{s}$ は，男女別に構築する．体格差を考慮するた めに用いる補正式を下に示す．各パラメータについては，重回帰解析を行い求めた。

$$
\left(\begin{array}{c}
l_{i} \\
d_{i} \\
\Delta \varphi_{s_{0}} \\
l_{s}
\end{array}\right)=\boldsymbol{A}\left(\begin{array}{c}
S \varphi_{T} \\
S \\
\varphi_{T} \\
1
\end{array}\right)=\left(\begin{array}{cccc}
\alpha_{l_{i}} & \beta_{l_{i}} & \gamma_{l_{i}} & c_{l_{i}} \\
\alpha_{d_{i}} & \beta_{d_{i}} & \gamma_{d_{i}} & c_{d_{i}} \\
\alpha_{\Delta \varphi_{s_{0}}} & \beta_{\Delta \varphi_{s_{0}}} & \gamma_{\Delta \varphi_{s_{0}}} & c_{\Delta \varphi_{s_{0}}} \\
\alpha_{l_{s}} & \beta_{l_{s}} & \gamma_{l_{s}} & c_{l_{s}}
\end{array}\right)\left(\begin{array}{c}
S \varphi_{T} \\
S \\
\varphi_{T} \\
1
\end{array}\right)
$$

各变数のパラメータを表 2 から 5 に示す. 各係数には, 男女 54 名の X 線画像を用いた解析結果を利用する. ま た, 図 7 に式 (20) で求めた推定式を示し, 各推定式の重相関 $R$ を表 2 から 5 に示す. $l_{1}$ における分散分析の $\mathrm{p}$ 值 は, $2.45 \times 10^{-7}$ であり, $d_{1}$ の $\mathrm{p}$ 值は, $5.11 \times 10^{-17}$ である. 他の $l_{i}, d_{i}$ に足しても同等の $\mathrm{p}$ 值となっている. 女性 の $\Delta \varphi_{s}$ の分散分析の $\mathrm{p}$ 值は， 0.0587 であり，女性の $l_{s}$ の分散分析の $\mathrm{p}$ 值は， 0.0014 である．男性のおいても同等 の $\mathrm{p}$ 值となっている.

これまで腰仙椎アライメント推定に用いる, 椎体重心間距離 $l_{i}$, 表皮-椎体重心間距離 $d_{i}$ の值は, $\mathrm{X}$ 線画像から の平均值を用いてきた。そのため，54 名分で作成した平均值を利用した場合の推定精度 (Constant) と本手法を用 いた場合の精度 (Proposed) を比較する. 式 (21) から各被験者ごとの累積誤差を利用し累積平均誤差值 $E_{\text {sum }}[\mathrm{mm}]$ を求め, 椎体重心間距離 $l_{i}$, 表皮-椎体重心間距離 $d_{i}$ を評価する. $E_{t_{i}}$ は X 線画像の真值を示し, $E_{e_{i}}$ は推定値を示 す. $M$ は被験者数を示し, $N$ は各パラメータを推定部位を示す.

$$
E_{\text {sum }_{*}}=\frac{1}{M} \sum_{j=1}^{M}\left(\sum_{i=0}^{N}\left|E_{t_{i}}-E_{e_{i}}\right|\right)
$$

仙骨部補正角 $\Delta \varphi_{s_{0}}$ と腰仙椎アライメント座標原点に体格差 $l_{s}$ においても, 54 名分で作成した平均值を利用した場 合の推定精度 (Constant) と, 本手法で推定した場合の誤差 (Proposed) を比較する. 下式を用いて, 各 $E_{*}$ を求める.

$$
E_{*}=\frac{1}{M} \sum_{j=1}^{M}\left(\left|E_{t}-E_{e}\right|\right)
$$

図 8 にそれぞれの結果を示す. $l_{i}, d_{i}$ と $l_{s}$ については, 体格差補正を用いることにより, 誤差が減少しているこ とが分かる.このため, この 3 つのパラメータに関して本補正法の推定の有効性が示された。しかし, $\Delta \varphi_{s_{0}} に つ$ いては女性のみ有効であった。これは, 表 4 に示したように, 男性の重相関 $R$ が低いためである. 各腰部寸法の 体格差補正を用いることにより, 誤差を削減することが出来ている。このため, これらを用いて腰仙椎アライメ ントを推定することによって精度を向上させることが可能である. 
Table 4 Calibration parameters for correction angle $\Delta \varphi_{S_{0}}$ of sacral.

\begin{tabular}{c|c|c|c|c|c}
$\mathrm{a}$ & $\alpha_{\Delta \varphi_{s_{0}}}$ & $\beta_{\Delta \varphi_{s_{0}}}$ & $\gamma_{\Delta \varphi_{s_{0}}}$ & $c_{\Delta \varphi_{s_{0}}}$ & $R$ \\
\hline Male & -0.065 & -4.455 & 0.075 & 32.708 & 0.265 \\
Female & -0.018 & -12.081 & -0.010 & 42.580 & 0.335 \\
\hline
\end{tabular}

Table 5 Calibration parameters for distance $l_{s}$ correction of coordinates.

\begin{tabular}{c|c|c|c|c|c} 
& $\alpha_{l_{s}}$ & $\beta_{l_{s}}$ & $\gamma_{l_{s}}$ & $c_{l_{s}}$ & $R$ \\
\hline Male & -0.355 & 32.987 & 0.366 & -7.4945 & 0.530 \\
Female & -0.550 & 68.808 & 0.557 & -59.972 & 0.470 \\
\hline
\end{tabular}

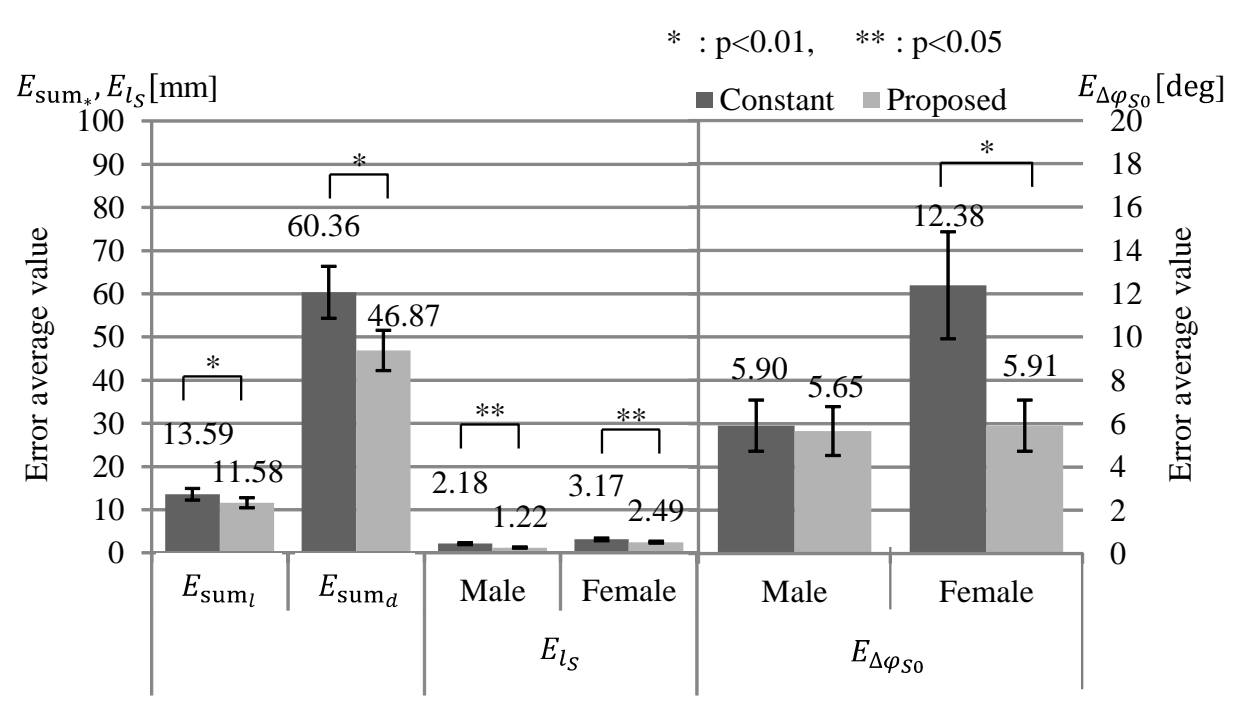

Fig. 8 Estimation error by using lumbosacral dimension calibration method.

Table 6 Subject's parameter of estimation experiment.

\begin{tabular}{c|c|c}
\hline & height $[\mathrm{cm}]$ & weight $[\mathrm{kg}]$ \\
\hline Male1 & 168.3 & 66.6 \\
Male2 & 177.4 & 75.7 \\
Male3 & 171.0 & 72.4 \\
Male4 & 179.1 & 67.0 \\
Female1 & 148.5 & 43.4 \\
Female2 & 154.8 & 50.0 \\
Female3 & 151.8 & 40.7 \\
Female4 & 160.4 & 51.5
\end{tabular}

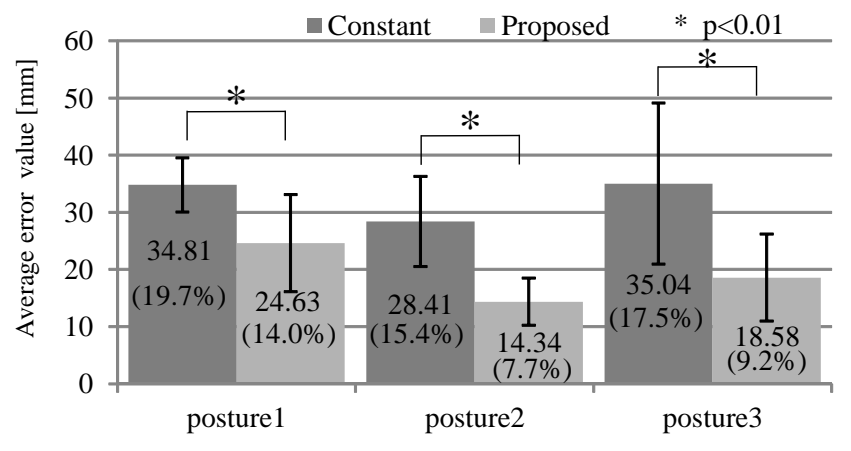

Fig. 9 Estimation of the lumbosacral alignment results, and the ratio of the error value to the lumbosacral length.

\section{4. 腰仙椎アライメント推定実験}

\section{$4 \cdot 1$ 実験方法と結果}

体格差補正と腰仙椎アライメント推定法の精度検証のため, 実際の腰仙椎アライメントと比較するために X 線 写真を用いて, 推定精度の検証を行う. ウェラブルセンサシステムが取得可能である各姿勢角および，各表皮曲率 をX 線画像から抽出した。それらの值を用いて腰仙椎アライメントを推定する。計測した姿勢は，X線撮影と同 様の直立姿勢 (posture1), 前屈姿勢 (posture2), 最大前屈姿勢 (posture3) である. 体格差補正の効果を確認するため に, 推定方法は, パラメータに定数值を用いた腰仙椎アライメント推定法 (Constant) と, 腰部寸法の体格差補正を 加えた腰仙椎アライメント推定 (Proposed) を行う. 被験者は男女各 4 名で評価を行う. 各被験者の身体特徵量を 表 6 に示す.ここでは, 本手法の前提条件である計測範囲の表皮曲率と椎体曲率の曲率中心符号が等しい被験者 を対象として解析を行う。 
Tsuchiya, Kusaka, Tanaka, Matsuo, Oda, Sasaki, Kamisima and Yamanaka,

Transactions of the JSME (in Japanese), Vol.82, No.843 (2016)

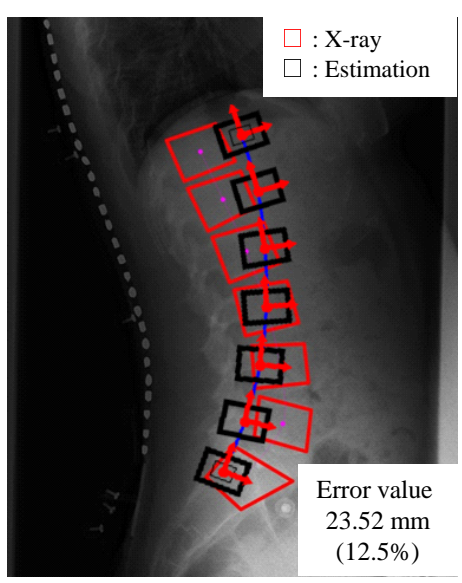

(a) posture 1 .

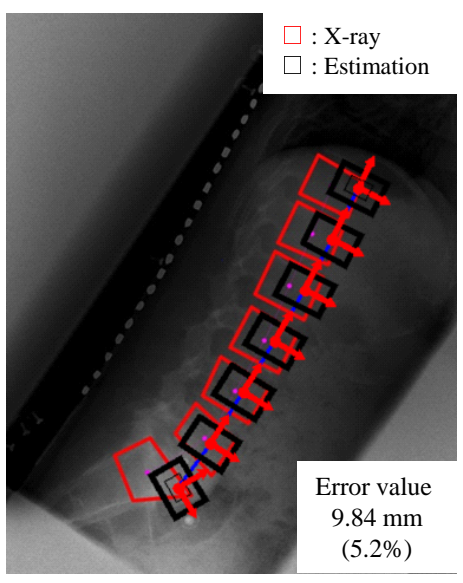

(b) posture 2

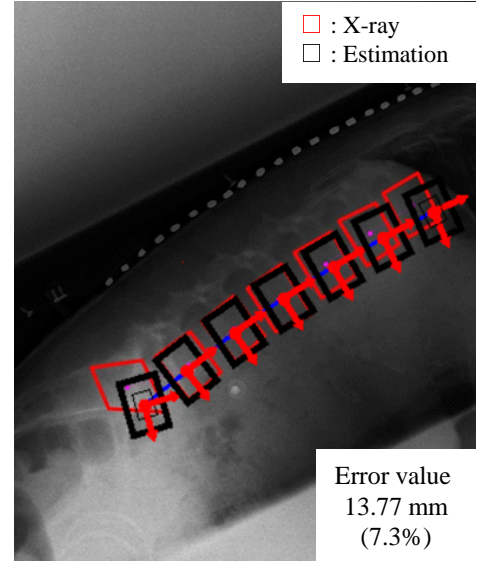

(c) posture 3 .

Fig. 10 Estimation of the lumbosacral alignment in each posture (Female1).

評価方法として，X 線写真から取得した各腰仙椎の重心位置 $R_{i}$ と，各手法で推定した各腰仙椎の重心位置 $b_{i}$ を 比較する．評価する条件として，座標系の原点から各腰仙椎座標の位置を比較する. 比較した各点の誤差の平均誤 差值を用いて評価する. 椎体 1 つあたりの平均誤差值を図 9 に示す. 図中の括弧内の数字は，腰仙椎長さに対す る誤差割合である。推定結果を同一姿勢の X 線画像に重ねた結果を図 10 に示す．赤の四角が X 線画像における 椎体，黒の四角が推定した椎体を示す.

\section{$4 \cdot 2$ 体格差を考慮した腰仙椎アライメント推定の考察}

体格差を考慮し，反映させることにより全ての姿勢に対して誤差の削減を確認した. 各姿勢に対して $\mathrm{t}$ 検定を 行った結果，全姿勢において $\mathrm{p}<0.01$ であり，体格差補正法の有意性が示せる. 全姿勢における 1 椎体あたりの誤 差平均は, $25.97 \mathrm{~mm}$ となる.このことは, 椎体 1 つ分のズレを示す. 腰仙椎長に対する誤差割合は平均 $10.32 \%$ と なっている．誤差は，仙椎アライメント推定のアルゴリズムが下部からの積み上げであるため，上部での誤差が 大きくなる．このため，今後は上部の姿勢を考慮したアライメント推定が必要だと考える.

先に述べたように，前提条件である計測範囲の表皮曲率と椎体曲率の曲率中心符号が等しかった被験者は今回 の X 線画像撮影の被験者の $15 \%$ であった曲率中心符号が異なる被験者の多くは，特に仙骨と腰椎を繋ぐ曲率と 表皮上での曲率が異なる場合である。また，この箇所を除く曲率中心符号に問題ない被験者は全体の $50 \%$ ある ため仙骨と腰椎における，表皮曲率と椎体曲率の関係を考慮した推定が必要となる．また，各腰仙椎には棘突起 が存在する．棘突起は表皮に近くSkin lineに接していると考えられる．このため，X線画像から各腰仙椎の棘突 起と椎体重心の関係を求めることにより, Skin line と棘突起の関係から腰仙椎アライメントの推定が行えると考 える。このことは，腰椎と仙骨部の解剖学的観点を本手法に取り入れる必要があることを示す.

一般的な腰部負荷の計算は上体の前屈角，身長と体重によって計算される (瀬尾，1999). 上体重心の位置によっ て腰部負荷が異なるものである. 本研究においても, 腰仙椎アライメントの推定誤差によって重心位置の誤差が 増えるため, 腰部負荷推定に誤差を生じる（土谷他，2014）。このため，体格差補正を加えることにより，腰部負 荷推定誤差の削減行える。今後は，腰部負荷に対しての検証を行っていく.

\section{$4 \cdot 3$ 試作したウェアラブルセンサシステムにおける腰仙椎アライメント推定誤差の予測}

我々が提案したウェアラブルセンサシステムのイメージを図 11 に示す。これまで我々が試作 (Tsuchiya et al., 2014)に用いたセンサ特性から，腰仙椎アライメント推定への影響を考える。曲率センサは Flex Sensor(Spectra symbol 社) を利用した。 このセンサの出力に対して, カットオフ周波数 $4 \mathrm{~Hz}$ のローパスフィルタ回路と計装アン プを用い 17 倍の増幅回路を通して, 曲率值を取得する. 曲率センサを 2 本 1 組とし, 前屈側と後屈側を計測でき るように組み合わせた。また，前屈側の曲率を正とし，後屈側の曲率を負とする。センサ特性は図 $12(\mathrm{a}) に$ 示すよ うに，線形性がある．曲率の計測範囲は， $\pm 6.00 m^{-1}$ となり，分解能は $0.01 m^{-1}$ である. 曲率センサの標準誤差は 
Tsuchiya, Kusaka, Tanaka, Matsuo, Oda, Sasaki, Kamisima and Yamanaka,

Transactions of the JSME (in Japanese), Vol.82, No.843 (2016)

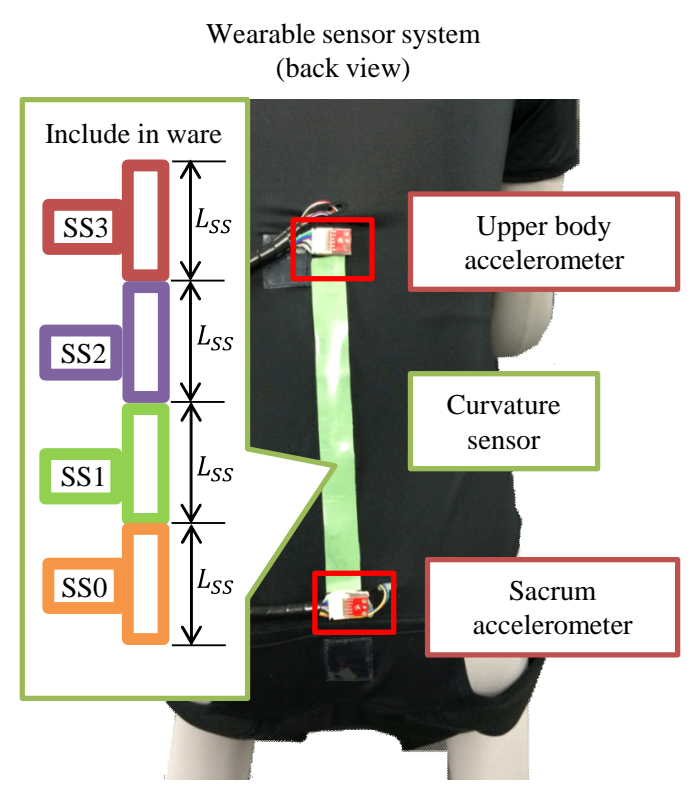

Fig. 11 Wearable sensor system prototype.

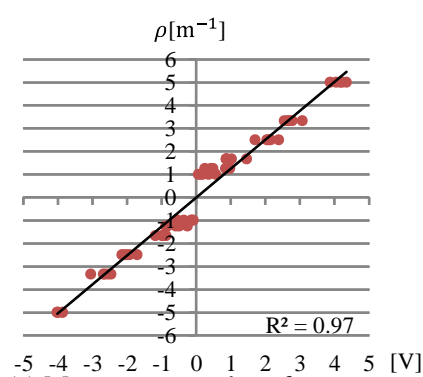

(a) Measurement value of curvature sensor.

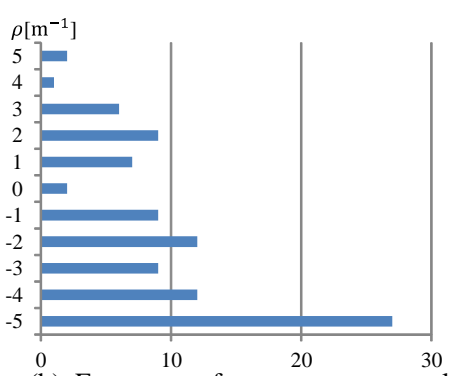

(b) Frequency of curvature sensor valu.

Fig. 12 Curvature sensor value

$0.46 m^{-1}$ である. 加速度センサは ADXL345(ANALOG DEVICE 社) を用いる. 重力加速度の計測範囲が $2 g$ であ り. 分解能は $0.007 \mathrm{~g}$ となる. 分解能分の誤差が存在すると, 0.4 度の誤差が考えられる.

これらのセンサ特性から，腰仙椎アライメント推定に影響を考える. Faemale1 の腰仙椎アライメント推定の際 に, 各センサに誤差を与える. 4 本の曲率センサに標準偏差分の誤差がある場合, 腰仙椎アライメント推定の累積 誤差は平均 $0.66 \mathrm{~mm}$ である. 図 12(b) に，腰仙椎アライメント推定で用いた曲率值の頻度を示す．計測精度の悪い と考えられる $\pm 2 m^{-1}$ の範囲は, 少ないことが図 12(b) から読み取れる. しかし，式 (9) のように $\frac{1}{\rho}$ とるる項があ るため, 計測感度の悪い位置ので影響は大きい。このため, 曲率センサの改良及び, 解剖学的知見から曲率中心を 利用しない腰仙椎アライメント推定用に改善する必要がある. 仙骨加速度センサから求めた骨盤姿勢角 $\varphi_{s_{0}}$ の誤差 が 0.4 度に対して, 腰仙椎アライメント推定の累積誤差は平均 $1.35 \mathrm{~mm}$ である. 曲率センサによる誤差に比べて, 加速度センサの誤差が腰仙椎アライメント推定法に与える影響が大きいと予測される。ただし，各センサが体に 密着している必要がある.

また，体格差補正による腰仙椎アライメント推定によって，体格差補正なしに比べ平均 $51.87 \mathrm{~mm}$ の誤差削減が 行えている，センサによる誤差よりも，体格差補正による誤差削減值が大きいため，ウェアラブルセンサシステ ムを用いて腰仙椎アライメント推定を行った場合，体格差補正による精度向上の効果がある.

\section{5. 結言}

腰椎形状を測定するシステムとしてウェアラブルセンサシステムのセンサ構成の検討を行った. 腰仙椎アライ メント推定法を構築した。体格差を考慮するために，腰部 X 線画像に基づき体格差補正を構築した。体格差のパ ラメータとして, 椎体重心間距離, 表皮-椎体重心間距離, 仙骨部補正角と, 腰仙椎アライメント座標の補正法を 構築した. 各パラメータの推定精度について評価を行い，補正法の有効性を示した。これらを組み合わせること により，体格差を考慮した腰仙椎アライメント推定が行うことができ，腰仙椎アライメントの推定精度を向上さ せた。ウェアラブルセンサシステムの試作に用いたセンサ特性から，センサの計測誤差の影響を論じた。しかし， 高精度なアライメント推定には解剖学の観点を本手法に取り入れる必要がある.

今後の課題として，ウェラブルセンサシステムを用いた腰仙椎アライメント推定精度及び，再現性を検証する. 推定精度の向上ために，上体加速度センサと仙骨加速度センサを利用した腰仙椎アライメント推定法を構築する. 
Tsuchiya, Kusaka, Tanaka, Matsuo, Oda, Sasaki, Kamisima and Yamanaka,

Transactions of the JSME (in Japanese), Vol.82, No.843 (2016)

そして, 腰仙椎の棘突起と腰部表皮形状との関係を解剖学的観点から加えることにより, 推定精度を高める.ま た, 腰仙椎アライメントの推定結果を用いて腰部負荷推定值を計算し評価を行う.

謝辞

本研究は, JSPS 科研費 JP16J02052 の助成を受けたものです. 本研究を進める上で，適切なご助言を下さった北 海道大学金子俊一教授に感謝いたします.

文献

ライフサイエンス統合データベースセンター，BodyParts3DC， licensed by CG 表示-継承 2.1 日本 (2013)

遠藤維, 多田充徳, 持丸正明, モーションキャプチャを用いた個人別デジタルハンドモデルの構築, 精密工学会 誌, Vol.79, No.9(2013), pp.860-867.

Farag, E. and Salem, M., An evaluation of the NIOSH lifting equation: a psychophysical and biomechanical investigation, International Journal of Occupational Safety and Ergonomics Vol.8, No.2(2002), pp.243-258.

Hoshina, H., Tanaka, T., Nara, H., Kaneko, S., Yamanaka, M. and Sekinoyama, k., An estimation of shape of lumbar spine based on measuring lumbar skin shape and angle of upper body for an estimation of lumbar burden, First IEEE Healthcare Technology Conference: Translational Engineering in Health \& Medicine(2012), pp287-290.

Itoh, H., Kitamura, F. and Yokoyama, K., Estimates of annual medical costs of work-related low back pain in Japan, Industrial health, Vol.51, No.5(2013), pp524-529.

Jger, M. and Alwin, L., Critical survey on the biomechanical criterion in the NIOSH method for the design and evaluation of manual lifting tasks, International journal of industrial ergonomics, Vol.23, No.4(1999), pp.331-337.

河崎尚史, 伊藤博一, 眞瀬垣啓, 小野大輔, 渡會公治, 立位, 坐位, 四這い姿勢における脊椎矢状面アライメン 卜・可動性の比較, 体力科學, Vol.58, No.5(2009), pp.517-526.

Kirkwood, R. N., Culham, E. G. and Costigan, P., Radiographic and non-invasive determination of the hip joint center location: effect on hip joint moments, Clinical Biomechanics, Vol.14.No.4(1999), PP.227-235.

藏澄美仁, 堀越哲美, 土川忠浩, 松原斎樹, 日本人の体表面積に関する研究, 日本生気象学会雑誌, Vol.31, No.1(1994), pp.5-29.

松村将司, 宇佐英幸, 小川大輔, 市川和奈, 畠昌史, 見供翔, 竹井仁, 健常成人における骨盤と下肢アライメントの年代 比較と性差の分析，日本理学療法学術大会 2012(2013) pp.48100760-48100760.

厚生労働省，職場における腰痛予防対策指針 (online), available from $<$ http://www.mhlw.go.jp/stf/houdou/youtsuushishin.html>, (参照日 2013 年 6 月 18 日).

Nachemson, Alf L. : The lumbar spine: an orthopaedic challenge, Spine, Vol1, No.1(1976), pp.59-71.

Occupational Safety \& Health Administration, Guidelines for nursing homes, Ergonomics for the Prevention of Musculoskeletal Disorders (ID 3182) U.S.A.(2003).

瀬尾明彦, 近藤雄二, 日下幸則, 腰部負担軽減のための作業再設計支援ソフト, 産業衛生学雑誌, Vol.40(1998), pp.349.

瀬尾明彦，産業現場における作業負担の計測と評価に関する研究，産業衛生学雑誌，Vol.41(1999), pp.150-151.

芝田京子, 井上喜雄, 岩田祥孝, 片川準也, 藤井涼, 腰椎系における椎間板負荷の非侵襲的な推定法, 日本機械 学会論文集 C編, Vol.78, No.791(2012), pp.2483-2495.

但野茂，石川博將，伊東学，金田清志，生体内椎間板矢状面に生じるひずみ分布，日本機械学会論文集 A 編，Vol.57, No.537(1991), pp.1202-1207.

独立行政法人産業技術総合研究所 デジタルヒューマン工学研究センター, AIST 人体寸法・形状データベース 2003(2009)

Tsuchiya, Y., Yoshikazu, M. and Takayuki, T., Estimation of lumbar load by 2D reconstruction of spine line using wearable sensor system, Systems, Man and Cybernetics (SMC), 2014 IEEE International Conference on IEEE(2014), pp.3669-3674.

土谷圭央, 日下聖, 松尾祥和, 田中孝之, 作業負担評価のためのウェアラブル腰部負荷推定システム, 産業保健 人間工学研究, 16(2014) pp.68-71. 
山根卓也, 舩冨卓哉, 飯山将晃, 美濃導彦, データグローブのセンサデータに基づく各指節の位置・向きの推定 手法の検討, 電子情報通信学会技術研究報告. PRMU, パターン認識・メディア理解, Vol.111, No.353(2011), pp.77-82.

山崎信寿, 山本真路, 井上剛伸, 移乗介助動作の計測と腰部負担の評価, バイオメカニズム, Vol.16(2002), pp.195205.

\section{References}

Database Center for Life Science, BodyParts3D(C), licensed under CC display Alike 2.1 Japan(2013)(in Japanese).

Endo, Y., Tada, M. and Mochimaru, M., Reconstruction of digital hand models for individuals by using motion capture system, Journal of the Japan Society for Precision Engineering, Vol.79, No.9(2013), pp.860-867(in Japanese).

Farag, E. and Salem, M., An evaluation of the NIOSH lifting equation: a psychophysical and biomechanical investigation, International Journal of Occupational Safety and Ergonomics Vol.8, No.2(2002), pp.243-258.

Hoshina, H., Tanaka, T., Nara, H., Kaneko, S., Yamanaka, M. and Sekinoyama, k., An estimation of shape of lumbar spine based on measuring lumbar skin shape and angle of upper body for an estimation of lumbar burden, First IEEE Healthcare Technology Conference: Translational Engineering in Health \& Medicine(2012), pp287-290.

Itoh, H., Kitamura, F. and Yokoyama, K., Estimates of annual medical costs of work-related low back pain in Japan, Industrial health, Vol.51, No.5(2013), pp524-529.

Jger, M. and Alwin, L., Critical survey on the biomechanical criterion in the NIOSH method for the design and evaluation of manual lifting tasks, International journal of industrial ergonomics, Vol.23, No.4 (1999), pp.331-337.

Kawasaki, S., Ito, H., Masegaki, A., Ono, D. and Watarai, K., Comparison of spinal sagittal alignment and mobilty among standing, sitting, and four point kneeling postures, The Japanese Society of Physical Fitness and Sports Medicine, Vol.58, No.5(2009), pp.517-526(in Japanese).

Kirkwood, R. N., Culham, E. G. and Costigan, P. Radiographic and non-invasive determination of the hip joint center location: effect on hip joint moments, Clinical Biomechanics, Vol.14.No.4(1999), PP.227-235.

Kurazumi, Y., Horikoshi, T., Tsuchikawa, T. and Matsubara, N., The body surface area of japanese, Japanese Society of Biometeorology, Vol.31， No.1(1994), pp.5-29(in Japanese).

Matumura, S., Usa, H., Ogawa, D., Ichikawa, K., Hata, M., Mitomo, S. and Takei, H., Kenjoseijin niokeru kotsuban to kashi araimento no nendai hikaku to seisa no bunseki, Congress of the Japanese Physical Therapy Association2012(2013) pp.48100760-48100760(in Japanese).

Ministry of Health, Labour and Welfare, Guidelines on the prevention of low back pain in the workplace, Ministry of Health(online), available from <http://www.mhlw.go.jp/stf/houdou/youtsuushishin.html>, (accessed on $18 \mathrm{June}$, 2013)(in Japanese).

Nachemson, Alf L. : The lumbar spine: an orthopaedic challenge, Spine, Vol.1, No.1(1976), pp.59-71.

Occupational Safety \& Health Administration, Guidelines for nursing homes, ergonomics for the prevention of musculoskeletal disorders (ID 3182) U.S.A.(2003).

Seo, A., Kondo, Y. and Kusaka, Y., A simple supporting software for redesigning working conditions to reduce low back load. , Journal of occupational health, Vol.40(1998), pp.349(in Japanese).

Seo, A., Measurement and evaluation of workload in workplace, Journal of occupational health, Vol.41(1999), pp.150-151(in Japanese).

Shibata, K., Inoue, Y., Iwata, Y., Katagawa, J. and Fujii, R., Study on noninvasive estimate method for intervertebral disk load at lumbar vertebrae, Transactions of the Japan Society of Mechanical Engineers, Series C, Vol.78, No.791(2012), pp.2483-2495(in Japanese).

Tadano, S., Ishikawa, H., Itoh, M. and Kaneda, K., Strain distribution on the sagittal plane of an intervertebral disc, Transactions of the Japan Society of Mechanical Engineers, Series A, Vol.57, No.537(1991), pp.1202-1207(in Japanese).

The National Institute of Advanced Industrial Science and Technology Digital Human Research Center, AIST/HQL Human body size $\cdot$ shape database2003(2009), (in Japanese). 
Tsuchiya, Kusaka, Tanaka, Matsuo, Oda, Sasaki, Kamisima and Yamanaka,

Transactions of the JSME (in Japanese), Vol.82, No.843 (2016)

Tsuchiya, Y., Yoshikazu, M. and Takayuki, T., Estimation of lumbar load by 2D reconstruction of spine line using wearable sensor system, Systems, Man and Cybernetics (SMC), 2014 IEEE International Conference on IEEE(2014), pp.3669-3674.

Tsuchiya, Y., Kusaka T., Yoshikazu, M. and Takayuki, T., Wearable lumbar load estimation system for work load evaluation, Journal of ergonomics in occupational safety and health, 16(2014) pp.68-71(in Japanese).

Yamane, T., Funatomi, T., Iiyama, M. and Minoh, M., Estimation of rigid transformation of finger segments from data glove, technical report of the institute of electronics, Information and Communication Engineers.PRMU, Vol.111, No.353(2011), pp.77-82(in Japanese).

Yamazaki, N., Yamamoto, S. and Inoue, T., Measurement of transferring motions and evaluation of caregiver's lowerback load, Biomechanisms, Vol.16(2002), pp195-205(in Japanese). 